\title{
SEISMIC ANALYSIS AND DESIGN OF IRREGULAR COMPOSITE STEEL-CONCRETE STRUCTURE AND ITS COMPARISON WITH RCC STRUCTURE
}

\author{
Vidhya C \\ M.Tech Student in Cads Structures \\ Civil Engineering Department \\ Malnad College of Engineering, Hassan
}

\begin{abstract}
In developing countries like India, the increase in the population creates demand for high rise structures for which we are facing scarcity of land. In present situation it has become necessary to consider economy of the structure which is more important. Generally we have RCC type of structures for the construction of Multi storied buildings. As we all know RCC building requires bulky size of components that increases the self weight of the structure which in turn increases cost of construction. Therefore to overcome this cause resulted in the practice of new innovative and efficient building method, which is Composite steel-concrete structure. Composite structure is a type of building method consisting of composite beam, composite column and composite deck slab which is connected with shear connectors. Composite structure consists of both steel and concrete resulting in better ductile behavior than that of RCC system. In this study 10 storied building is considered which is modeled and dynamic analysis is carried out with the use of ETABS software. Results from both the type of structure are compared and concluding that which structure is more recommendable and economical.
\end{abstract}

Keywords- Composite structure, RCC (Reinforced Cement Concrete) structure, Composite beam, Seismology, Seismic weight, Storey stiffness.

\section{INTRODUCTION}

In developing countries like India, use of steel in the construction industry is very low. Though India has a great potential for increasing the volume of steel, we are experiencing a lack of usage of steel in construction industry which indirectly effecting the economy of the country. Now-adays use of composite section which is steel encased with concrete is becoming more effective for the construction of high rise building and bridges. Composite sections are economic, cost and time effective for building construction. For low-rise structures RCC construction is found to be more

\author{
Dr. H. S. Narashimhan \\ Associate Professor \\ Civil Engineering Department \\ Malnad College of Engineering, Hassan
}

sufficient because of action of gravity loads alone, whereas in case of medium and high rise structure we have to face the action of both gravity and lateral loads such as earthquake (seismic) and wind load. Use of composite construction is one such method with which we can achieve safety and economy.

\section{DifFERENT METhods OF BUILDING CONSTRUCTION}

A. Concrete structures - It is the most commonly used construction material across the world. Concrete csn only take compressive stresses effectively and it cannot take tensile stresses. So in order to withstand tensile loads, reinforcement is given to concrete. Because of its durability and compatibility, concrete is widely used today in construction industry. Concrete has a property to mould in any shape that makes it most useful. These stuctures can be made with many different ways such as Plain Cement Concrete, Reinforced Cement Concrete and Pre-stress Concrete.

$B$. Steel structures - It is an alloy of iron and small carbon percentage and other elements, for example silicon, phosphorous and sulphur in varying percentage. Different types of steel used are mild steel, medium carbon steel, high carbon steel, low alloy steel. Structural steel is used for building purposes. Steel which is used for the manufacture of structural elements such as rolled steel elements, fastenings and various other elements for the use in structural steel works is known as structural steel. It has been standardized by Indian Standard Institution for the use of proper quality of steel.

C. Composite steel-concrete structures - It is defined as structures in which composite action exist by bounding two different materials together so strongly that they act together act as a single unit forming structural action criteria. In general it may be steel beams supporting concrete floor slabs. The unique feature of composite structures is that it will reduce overall weight of the structure, increased performance and also increases economy of the construction. This type of 


\section{International Journal of Engineering Applied Sciences and Technology, 2020 \\ Vol. 5, Issue 5, ISSN No. 2455-2143, Pages 229-234 \\ Published Online September 2020 in IJEAST (http://www.ijeast.com)}

construction is dominating over more than a decade due to strength and stiffness achieved with minimum use of materials.

\section{LITERATURE REVIEW}

Prof. Rajendra R. Bhoir., et.al. (2017) studied seismic performance of the composite steel-concrete structures and the result is compared with RCC structures. In their work, authors have performed the static analysis on $\mathrm{G}+15$ multi-storied regular composite and RCC structure using E-tabs software. They have considered two models by changing floor heights in two models. The work is carried out on commercial building, and then the result is tabulated and compared in terms of volume of construction material such as concrete, Reinforcing steel and Structural steel and other result parameters are cost of both composite and RCC structure, axial force, bending moment. They concluded that composite structure reduces the overall cost of the structure and increases the economy of the construction by minimizing the requirement of basic construction materials. Considering Earthquake factor, since composite structure has inherent ductility characteristics it performs better under the action of lateral loads than RCC structure.

K. Mukesh kumar and H. Sudarshana Rao., et.al. (2016) studied Seismic behavior of composite structure and it is compared with RCC structures. In their work, authors have considered three different models by differentiating them from low to high rise RCC and Composite structures say 5, 10 and 15 storied regular structure. Seismic analysis is carried out for earthquake zone IV which is said to be worst case or scenario. Here they have carried out dynamic analysis which includes Non-linear Time-history analysis and Response Spectrum analysis. E-tabs software is been used for modeling and analysis. The comparison of the seismic response on the displacement, story drifts, column axial forces, column bending moments and shear forces, beam shear forces and bending moments, time period of the structure and dead weight of the structure. They concluded that increased stiffness parameter in RCC structure leading to less time period and making it less flexible than RCC, maximum displacements and drifts is observed in composite structures since it is more flexible and dead weight of the composite structure is less than RCC structure because of usage of thin sections making the structure less susceptible against seismic force acting on structure.

A.S. Mahajan and L.G. Kalurkar., et.al. (2016) compared the behavior of high rise composite and RCC building using E-tabs 2015 software. Their work made us to understand the fact that application of composite model is not just habitable, stable and safe but also time saving and cost effective. They carried out analysis on G+20 multi storied building for which American standards provisions are considered for composite building and the conventional RCC structure is designed according to IS 456-2000. Seismic assessment and comparison is done considering different parameters such as bending moment, shear force, base shear, cost of structure, Time period and weight of structure are studied for composite and RCC model. Response spectrum analysis is carried out for knowing seismic performance. They concluded that composite structure performs better in every aspect than RCC structure.

Umesh Rajendra Tubachi and Manohar. K., et.al. (2019) carried out analysis of steel concrete composite structure and its comparison with RCC structure. In this work they have considered $\mathrm{G}+30$ high rise regular building and analysis is done with the help of E-tabs software, and working out analysis considering static, dynamic and wind analysis. Results are compared with the help of plotting graphs. Composite structure is analyzed using American standards and for RCC structures Indian codes has been used. They concluded that in terms of dead load of structure, storey drift, displacement and torsion moment of composite structure is lesser than the RCC structure making it more preferable for the adoption in construction industry.

Venkateswar Reddy. K., et.al. (2019) carried out seismic behavior of steel-concrete composite structure using Euro code. In this work authors have analyzed behavior of composite beam using ANSYS and SAP software; and also analysis of $\mathrm{G}+3$ residential building is analyzed using STAAD Pro software. Column end moments and Beam maximum moments is tabulated and concluded that dead weight of structure is much lesser than RCC building; composite column has more flexural stiffness than the RCC section.

\section{OBJECtives of PRESENT InVESTIGATION}

- To study the response of composite steel-concrete building subjected to lateral loads such as seismic loads.

- To study the importance of steel in the construction industry and its application to multi-storied irregular building.

- To analyze the behavior of the composite steel-concrete building for the critical earthquake zone scenario.

- To compare the RCC and Composite steel-concrete structures and concluding the results considering parameters such as dead weight, storey deflection, storey drift, base shear etc.

\section{SEISMiC ANALysis of RCC AND COMPOSITE STRUCTURES}

Seismic Analysis is carried out to determine the effect of earthquake load on the structure. Seismic analysis is done in order to determine the seismic response which is necessary for high rise buildings since they are more vulnerable to seismic activity. Load parameters are considered as per IS: 875 Part 1 and 2 for both RCC and Composite structures whereas Seismic parameters for RCC model is as per IS: 1893-2002 and for composite model is as per AISC 7-10. 


\section{International Journal of Engineering Applied Sciences and Technology, 2020 \\ Vol. 5, Issue 5, ISSN No. 2455-2143, Pages 229-234 \\ Published Online September 2020 in IJEAST (http://www.ijeast.com)}

Methods of seismic analysis includes following four types:

- Linear Static Analysis

- Nonlinear Static Analysis

- Linear Dynamic Analysis

- Nonlinear Dynamic Analysis

Details of RCC model:

TABLE I

BUILDING DETAILS

\begin{tabular}{|c|c|c|}
\hline Sl.No & Quantity & Preliminary data \\
\hline 1 & Plan dimension & $44.14 \mathrm{~m} \times 47.995 \mathrm{~m}$ \\
\hline 2 & Height of the building & $30.00 \mathrm{~m}$ \\
\hline 3 & Height of each storey & $3.00 \mathrm{~m}$ \\
\hline 4 & Size of beam & $\begin{array}{l}300 \times 600 \mathrm{~mm}, 300 \times 650 \mathrm{~mm} \\
300 \times 700 \mathrm{~mm}, 300 \times 750 \mathrm{~mm}\end{array}$ \\
\hline 5 & Size of column & $300 \times 900 \mathrm{~mm}, 300 \times 1200 \mathrm{~mm}$ \\
\hline 6 & Slab thickness & $125 \mathrm{~mm}$ \\
\hline 7 & Wall thickness & $200 \mathrm{~mm}$ \\
\hline 8 & Grade of concrete & $30 \mathrm{~N} / \mathrm{mm} 2$ \\
\hline 9 & Grade of steel & $500 \mathrm{~N} / \mathrm{mm} 2$ \\
\hline 10 & Live load & $2.00 \mathrm{kN} / \mathrm{m} 2$ \\
\hline 11 & Floor finish & $1.20 \mathrm{kN} / \mathrm{m} 2$ \\
\hline 12 & Wall load & $10.00 \mathrm{kN} / \mathrm{m}$ \\
\hline 13 & Partition load & $5.00 \mathrm{kN} / \mathrm{m}$ \\
\hline 14 & Earthquake zone & $\mathrm{V}$ \\
\hline 15 & Zone factor & 0.36 \\
\hline 16 & Importance factor & 1.00 \\
\hline 17 & Soil type & Hard soil \\
\hline 18 & $\begin{array}{l}\text { Response reduction } \\
\text { factor }\end{array}$ & 3.00 \\
\hline 22 & $\begin{array}{l}\text { Fundamental natural } \\
\text { period }\end{array}$ & $0.40 \mathrm{sec}$ \\
\hline
\end{tabular}

ETABS model:

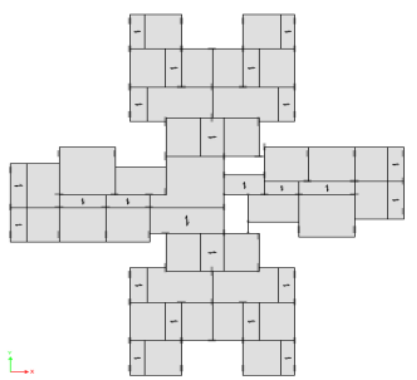

Fig 1: ETABS plan of RCC model

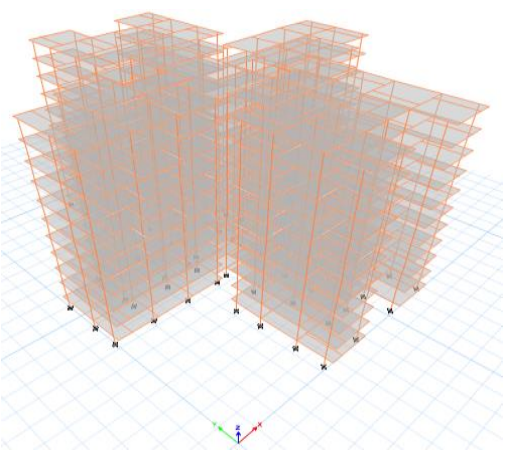

Fig 2: Isometric view of RCC model

Details of Composite model:

TABLE II

BUILDING DETAILS

\begin{tabular}{lll}
\hline \hline Sl.No & Quantity & Preliminary data \\
\hline 1 & Plan dimension & $44.14 \mathrm{~m} \times 47.995 \mathrm{~m}$ \\
2 & Height of the building & $30.00 \mathrm{~m}$ \\
3 & Height of each storey & $3.00 \mathrm{~m}$ \\
4 & Size of beam & W18 x 130 \\
5 & Size of column & W18 x $106,450 \times 650 \mathrm{~mm}$ \\
6 & Slab thickness & $125 \mathrm{~mm}$ \\
7 & Wall thickness & $200 \mathrm{~mm}$ \\
8 & Grade of concrete & $4000 \mathrm{psi}$ \\
9 & Grade of steel & A992fy50 \\
10 & Live load & $2.00 \mathrm{kN} / \mathrm{m} 2$ \\
11 & Floor finish & $1.20 \mathrm{kN} / \mathrm{m} 2$ \\
12 & Wall load & $10.00 \mathrm{kN} / \mathrm{m}$ \\
13 & Partition load & $5.00 \mathrm{kN} / \mathrm{m}$ \\
14 & Earthquake zone & V \\
15 & Zone factor & 0.36 \\
16 & Importance factor & 1.00 \\
17 & Soil type & Hard soil \\
18 & Response reduction & 3.00 \\
22 & factor & \\
& Fundamental natural & $0.96 \mathrm{sec}$ \\
\hline \hline
\end{tabular}

ETABS model:

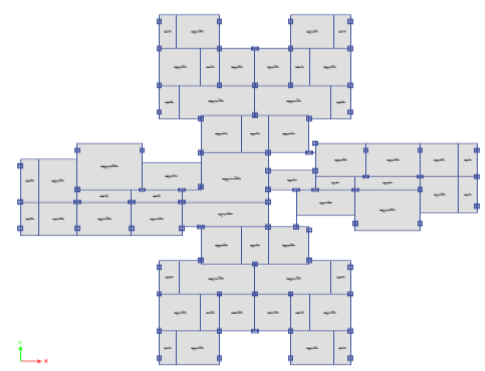

Fig 5: ETABS plan of Composite model 
International Journal of Engineering Applied Sciences and Technology, 2020

Vol. 5, Issue 5, ISSN No. 2455-2143, Pages 229-234

Published Online September 2020 in IJEAST (http://www.ijeast.com)

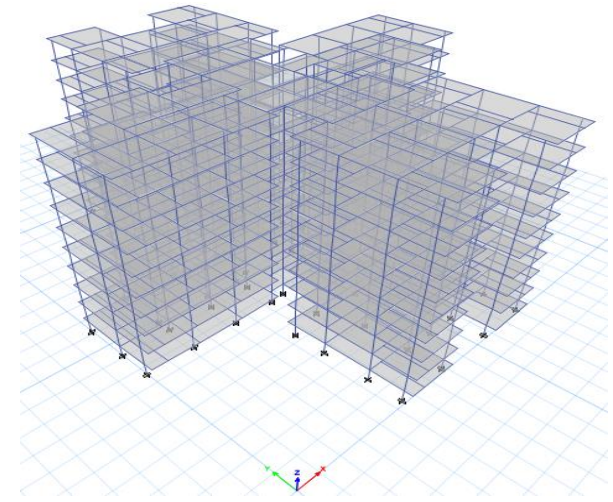

Fig 6: Isometric view of Composite model

\section{RESULTS AND DISCUSSION}

RESULTS:

1) Storey displacement

TABLE III

MAX STOREY DISPLACEMENT

\begin{tabular}{|c|c|c|c|c|}
\hline \multirow[t]{2}{*}{ Sl.No } & \multicolumn{2}{|c|}{ RCC STRUCTURE } & \multicolumn{2}{|c|}{ COMPOSITE STRUCTUR } \\
\hline & $\mathrm{RS}_{\mathrm{x}}$ & $\mathrm{RS}_{\mathrm{y}}$ & $\mathrm{RS}_{\mathrm{x}}$ & $\mathrm{RS}_{\mathrm{y}}$ \\
\hline 10 & 56.392 & 39.979 & 45.356 & 26.754 \\
\hline 9 & 53.499 & 38.595 & 42.894 & 25.595 \\
\hline 8 & 49.171 & 36.418 & 39.54 & 23.959 \\
\hline 7 & 43.592 & 33.392 & 35.328 & 21.811 \\
\hline 6 & 37.652 & 29.579 & 30.383 & 19.186 \\
\hline 5 & 31.33 & 25.074 & 25.126 & 16.147 \\
\hline 4 & 24.478 & 19.992 & 19.397 & 12.773 \\
\hline 3 & 17.268 & 14.475 & 13.365 & 9.166 \\
\hline 2 & 10.04 & 8.736 & 7.323 & 5.471 \\
\hline 1 & 3.441 & 3.257 & 2.202 & 2.017 \\
\hline $\mathrm{B}$ & 0 & 0 & 0 & 0 \\
\hline 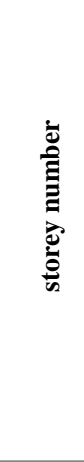 & $\begin{array}{lll}0 & 5 & 1 \\
& & \end{array}$ & $\begin{array}{l}253035 \\
\text { displace }\end{array}$ & - & $\begin{array}{l}\text { re } \\
\text { site } \\
\text { re }\end{array}$ \\
\hline
\end{tabular}

Chart 1: Max storey displacement in $x$-direction

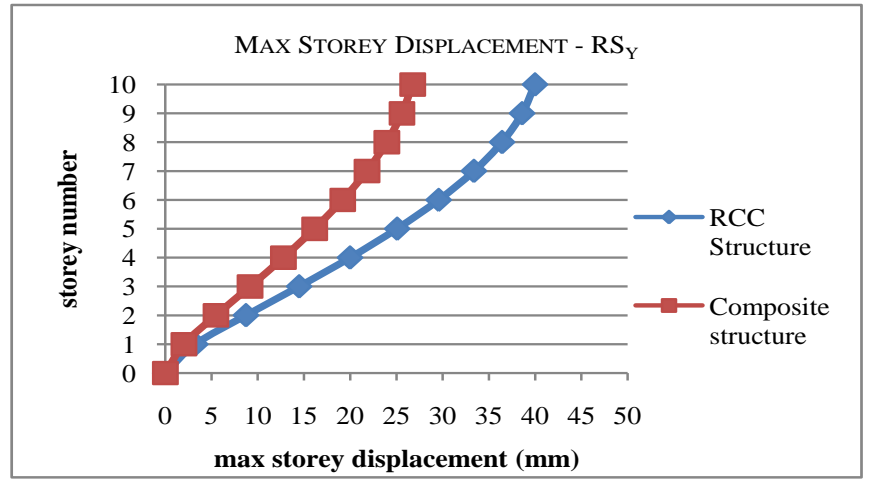

Chart 2: Max storey displacement in y-direction

2) Storey drift

TABLE IV

MAX STOREY DRIFT

\begin{tabular}{|c|c|c|c|c|}
\hline \multirow[t]{2}{*}{ Sl.No } & \multicolumn{2}{|c|}{ RCC STRUCTURE } & \multicolumn{2}{|c|}{ COMPOSITE STRUCTURE } \\
\hline & $\mathrm{RS}_{\mathrm{x}}$ & $\overline{\mathrm{RS}_{\mathrm{y}}}$ & $\mathrm{RS}_{\mathrm{x}}$ & $\overline{\mathrm{RS}_{\mathrm{y}}}$ \\
\hline 10 & 3.707 & 2.943 & 1.406 & 1.169 \\
\hline 9 & 5.455 & 4.057 & 2.209 & 1.65 \\
\hline 8 & 6.736 & 4.969 & 3.063 & 2.163 \\
\hline 7 & 6.807 & 5.592 & 3.847 & 2.639 \\
\hline 6 & 6.883 & 5.674 & 4.535 & 3.05 \\
\hline 5 & 7.189 & 5.981 & 5.107 & 3.38 \\
\hline 4 & 7.369 & 6.148 & 5.538 & 3.61 \\
\hline 3 & 7.286 & 6.077 & 5.756 & 3.696 \\
\hline 2 & 6.617 & 5.125 & 5.494 & 3.455 \\
\hline 1 & 3.441 & 2.202 & 3.257 & 2.017 \\
\hline $\mathrm{B}$ & 0 & 0 & 0 & 0 \\
\hline
\end{tabular}

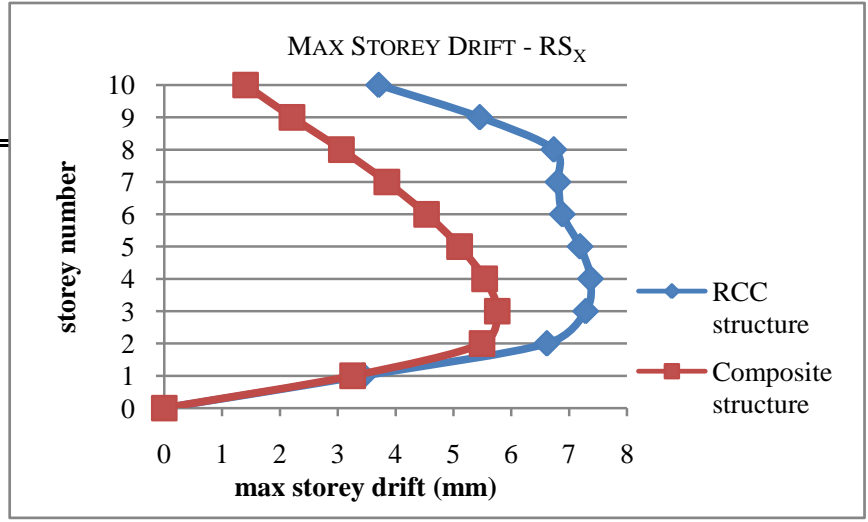

Chart 3: Max storey drift in $x$-direction 
International Journal of Engineering Applied Sciences and Technology, 2020

Vol. 5, Issue 5, ISSN No. 2455-2143, Pages 229-234

Published Online September 2020 in IJEAST (http://www.ijeast.com)

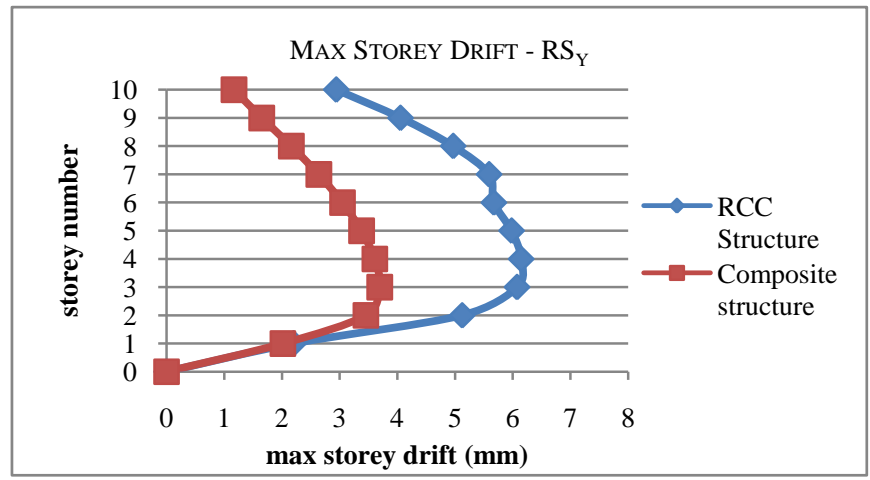

Chart 4: Max storey drift in y-direction

3) Storey stiffness

TABLE V

STOREY STIFFNESS

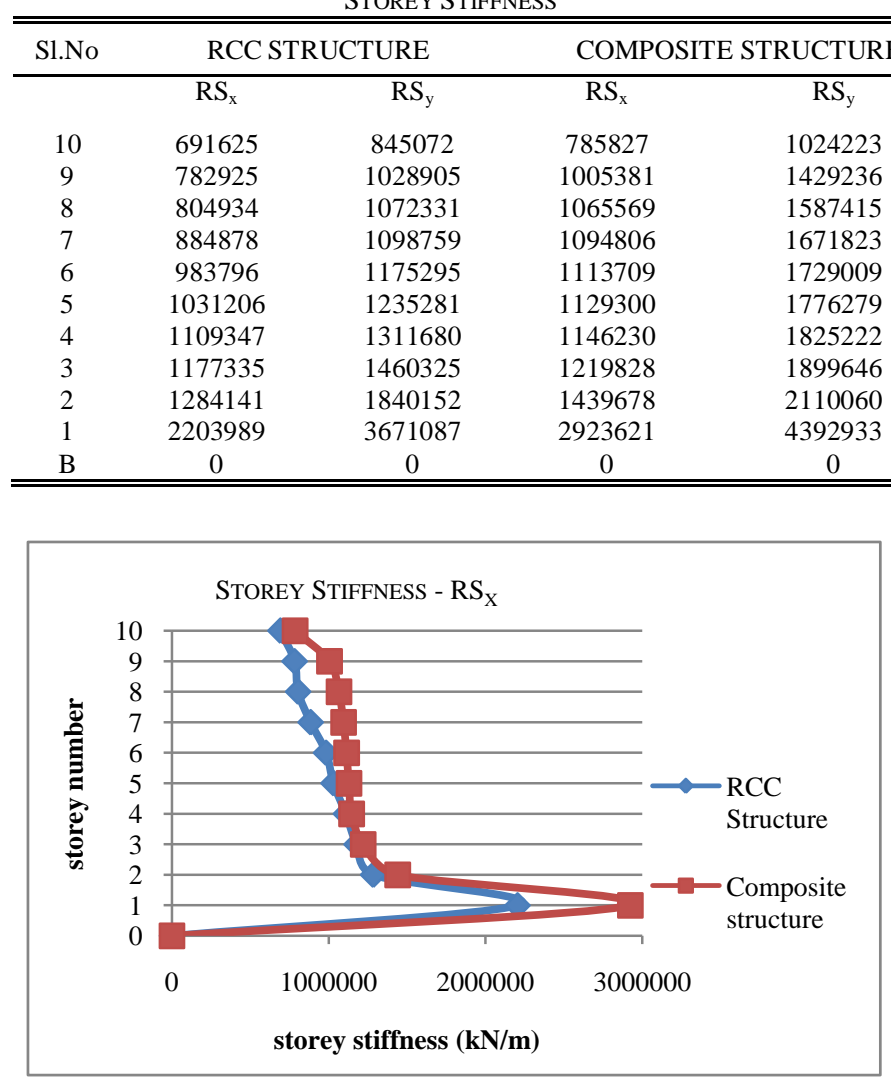

Chart 5: Storey stiffness in $x$-direction

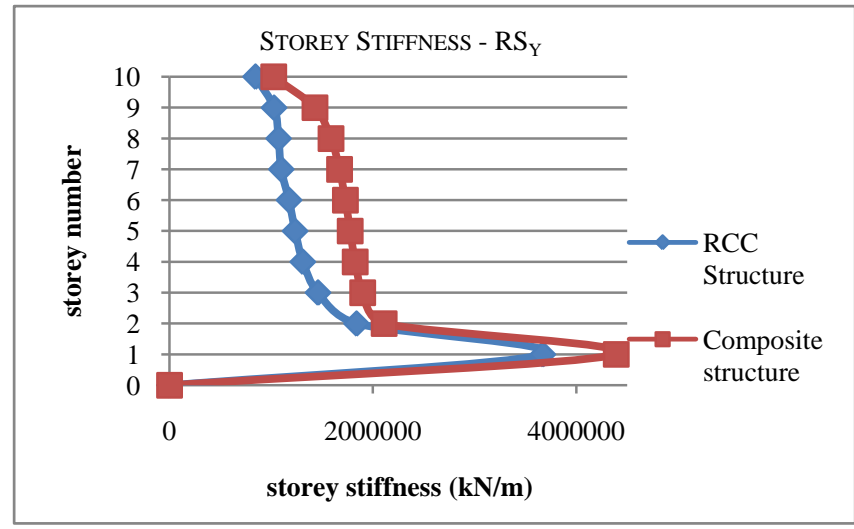

Chart 6: Storey stiffness in y-direction

4) Storey forces

TABLE VI

STOREY FORCES

\begin{tabular}{ccccc}
\hline S1.No & \multicolumn{2}{c}{ RCC STRUCTURE } & \multicolumn{2}{c}{ COMPOSITE STRUCTURE } \\
\hline & $\mathrm{RS}_{\mathrm{x}}$ & $\mathrm{RS}_{\mathrm{y}}$ & $\mathrm{RS}_{\mathrm{x}}$ & $\mathrm{RS}_{\mathrm{y}}$ \\
10 & 2424.54 & 2326.22 & 1055.16 & 1071.14 \\
9 & 4058.48 & 3984.20 & 2133.39 & 2158.51 \\
8 & 5145.49 & 5120.07 & 3138.86 & 3164.71 \\
7 & 5878.26 & 5893.32 & 4054.93 & 4074.89 \\
6 & 6471.11 & 6516.55 & 4867.17 & 4875.55 \\
5 & 7088.11 & 7135.18 & 5562.02 & 5554.40 \\
4 & 7771.89 & 7838.21 & 6126.30 & 6099.99 \\
3 & 8486.42 & 8542.38 & 6547.22 & 6501.51 \\
2 & 9111.87 & 9139.57 & 6813.20 & 6750.60 \\
1 & 9439.32 & 9401.27 & 6921.85 & 6848.96 \\
$\mathrm{~B}$ & 0.00 & 0.00 & 0.00 & 0.00 \\
\hline \hline
\end{tabular}

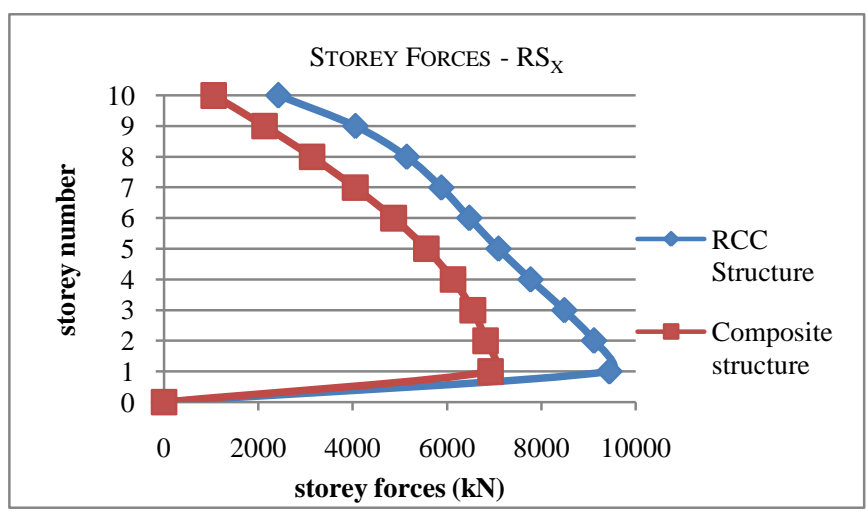

Chart 7: Storey forces in $x$-direction 


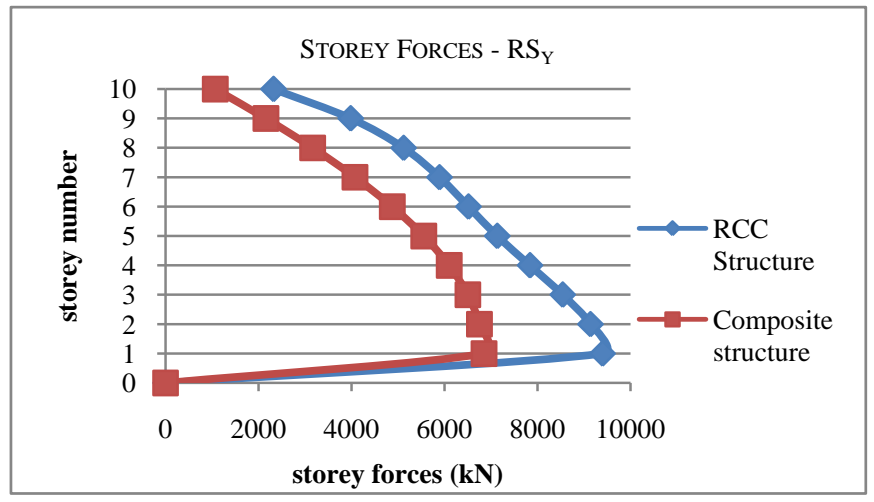

Chart 8: Storey forces in y-direction

\section{DISCUSSION:}

- Maximum storey displacement in composite structure is less when compared to RCC structure in both the direction.

- Maximum storey drift evaluated is minimum in composite structure compared to RCC structure in $\mathrm{x}$ and y direction respectively.

- Storey stiffness in composite structure is greater compared to RCC structure.

- Storey forces in composite structure is less when compared to RCC structure in both $\mathrm{x}$ and $\mathrm{y}$ direction respectively.

\section{CONCLUSION}

A. Max storey displacement of the composite structure is varying in between the range $20.00 \%$ to $36.00 \%$ less than the RCC structure.

B. Max storey drift of the composite structure is varying in between the range $10.00 \%$ to $60.00 \%$ less than the RCC structure.

C. Storey stiffness of the composite structure is $17.50 \%$ higher than RCC structure.

D. A storey force of the composite structure is less by $35 \%$ when compared to RCC structure.

\section{REFERENCES}

[1] Anuj Kumar Sharma, B. S. Tyagi. (April 2019)- A review on Comparative study on the seismic behavior of RCC and Composite Structures, Volume: 06, Issue: 04, pages: 3737-3741, e-ISSN: 2395-0056, www.irjet.net

[2] ASCE 7-10, Minimum Design Loads for Buildings and other Structures [American society of Civil Engineers].

[3] A. S. Mahajan, L.G. Kalurkar. (September 2016)Analysis of Composite Structures, Vol. No.4, Issue No. 09, pages: 254-263, ISSN: 2348-7550, www.ijates.com

[4] Dr. D. R. Panchal. (March 2014)- New techniques of Analysis and Design of Composite steel-concrete structures, Vol. 3 Issue 3, pages: 639-643, ISSN: 22780181, www.ijert.org

[5] IS-1893:2002 (Part-1) Criteria for Earthquake Resistant design of structure.

[6] IS-875(Part-1)-1987 used for Design loads (other than earthquake) for building and structure.

[7] IS-875(Part-2)-1987 used for Design loads (other than earthquake) for building and structure.

[8] IS-456: 2000 used for Plain and Reinforced concrete.

[9] K. Mukesh Kumar, H. Sudarsana Rao. (October 2016)Seismic Analysis of Composite Structure and its comparision with RCC structure, Volume 6 Issue No. 10, pages: 2703-2707, http://ijesc.org/

[10] Prof. Rajendra. R. Bhoir, Prof. Vinay Kamble, Prof. Darshana Ghankute. (September 2017)- Analysis and Design of Composite Structure and its Comparison with RCC Structure, Volume 5 Issue X, pages: 88-94, ISSN: 2321-9653, www.ijraset.com

[11] Shweta A. Wagh, Dr. U. P. Waghe. (April 2014)Comparative Study of RCC and Steel Concrete Composite Structures, Vol. 4, Issue 4( Version 1), pages: 369-376, ISSN: 2248-9622.

[12] Umesh Rajendra Tubachi, K. Manohar. (June 2019)Analysis of Steel Concrete Composite structure, Volume 9 Issue No. 6, pages: 23147-23152, ISSN: 2321 3361, http://ijesc.org/

[13] Venkateswar Reddy. K, Jugal Kishore M, M. Uday Bhaskar. (December 2019)- Seismic Behavior of steelconcrete Composite Structures, Volume-09 Issue-2, pages: 4721-4726, ISSN: 2249-8958, www.ijeat.org 